Dicle Tıp Dergisi / Dicle Med J (2019) 46 (4) : 813 - 820

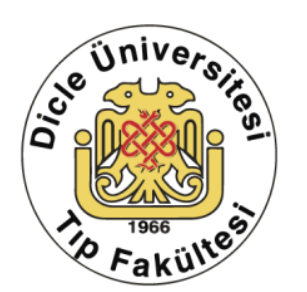

WWW.diclemedj.org

Özgün Araștırma / Original Article

\title{
Our Experiences of Pre-emptive Analgesia in Pediatric Penile Surgery: A Retrospective Comparison of the Analgesic Effects of Caudal Block and Dorsal Penile Block
}

\author{
Fikret Salık ${ }^{1}$, Hakan Akelma² \\ 1 Dept of Anesthesiology and Reanimation Diyarbakır Gazi Yaşargil Training and Research Hospital Diyarbakır 21010, Turkey ORCID: 0000-0002-7715-3545 \\ 2 Dept of Anesthesiology and Reanimation Diyarbakır Gazi Yaşargil Training and Research Hospital Diyarbakır 21010, Turkey ORCID: 0000-0002-0387-8738
}

Received: 19.09.2019; Revised: 0.511.2019; Accepted: 0.611.2019

\begin{abstract}
Objective: Postoperative analgesia control is very important in circumcision patients, so preemptive analgesia methods are widely used for this purpose. The aim of this study was to compare patients undergoing circumcision applied with the most commonly used preemptive analgesia methods of caudal block or dorsal penile block, between January 2016 and September 2017 in our hospital.

Methods: This retrospective study included 483 cases who underwent a circumcision operation at Ermenek State Hospital between January 2016 and September 2017 and were administered caudal block or dorsal penile block as preemptive analgesia. The anesthesia follow-up forms and nurse observation forms of the patients were examined and a record was made of demographic data, duration of surgery, duration of anesthesia, intraoperative and postoperative analgesic requirements and complications. From the clinics observation records of the patients, the time of first analgesic drug requirement and VAS scores were recorded.

Results: Demographic data and hemodynamic data were similar in both groups. When the two groups were compared, in the caudal group, the duration of postoperative analgesia was longer, fewer patients required additional analgesia in the first 6-hour period, and the VAS scores were lower $(\mathrm{p}<0.05)$. In both groups, the number of failed blocks and complication rates were similar ( $\mathrm{p}>0.05$ ).

Conclusion: It is easy and safe to administer caudal block or dorsal penile block with bupivacaine for preventive analgesia in children undergoing circumcision. However, caudal block is more effective in providing postoperative analgesia.
\end{abstract}

Keywords: Caudal block, dorsal penile block, complication, postoperative analgesia, circumcision. 


\section{Pediatrik Penil Cerrahisinde Preemptif Analjezi Deneyimlerimiz: Kaudal Blok ve Dorsal Penil Bloğun Analjezik Etkilerinin Retrospektif Olarak Karşılaştırılması}

\section{Öz}

Amaç: Sünnet hastalarında postoperatif analjezi kontrolü oldukça önemlidir. Bu amaçla preemptif analjezi yöntemleri yaygın olarak kullanılmaktadır. Bu çalışmanın amacı hastanemizde Ocak 2016-Eylül 2017 dönemleri arasında sünnet hastalarına uygulanmış ve farklı kliniklerde en sık uygulanan preemptif analjezi yöntemlerinden kaudal blok ve dorsal penil bloğun yeterli olup olmadığını retrospektrif olarak karşılaştırmaktır.

Yöntemler: Bu çalışma Ocak 2016-Eylül 2017 ayları arasındaki Ermenek Devlet Hastanesinde sünnet operasyonu geçiren ve preemtif analjezi amacıyla kaudal blok veya dorsal penil blok uygulanan 483 vakanın dosyalarının retrospektif olarak değerlendirildiği bir çalışmadır. Hastaların dosyalarındaki anestezi izlem formları ve hemşire gözlem formları incelenerek, hastaların demografik verileri, cerrahi süre, anestezi süresi, intraoperatif ve postoperatif analjezik ilaç ihtiyaçları ile verilme zamanlarına ve kaydedilen komplikasyonlara bakıldı. Hastaların servis gözlem kayıtlarından; ilk analjezik ilaç ihtiyaç süreleri, VAS skoru kaydedildi.

Bulgular: Her iki grupta demografik veriler ve hemodinamik veriler benzer bulundu. Her iki grup karşılaştırıldığında kaudal grupta postoperatif analjezi süresi daha uzun, ilk 6 saatlik dönemde ek analjezik ilaç ihtiyacı olan hasta sayısı daha az ve VAS skoru daha düşük bulundu $(\mathrm{p}<0,05)$. Her iki grupta da başarısız olan blok sayısı ve komplikasyon oranları benzer bulundu ( $\mathrm{p}>0,05)$.

Sonuç: Sünnet operasyonu geçiren çocuklarda preemptif analjezi amaciyla bupivakain ile kaudal blok veya dorsal penil bloğun uygulanması kolay ve güvenlidir. Ancak kaudal blok postoperatif analjezi sağlamada daha etkilidir ve daha çok hasta memnuniyeti sağlamaktadır.

Anahtar kelimeler: Kaudal blok, dorsal penis bloğu, komplikasyon, postoperatif analjezi, sünnet.

\section{INTRODUCTION}

Postoperative pain in children after penile surgery may have adverse effects such as causing agitation and anxiety, which then lead to stress and tension in the parents ${ }^{1,2}$. Pain control reduces complications and accelerates healing in the postoperative period, in addition to ensuring the comfort of both children and parents ${ }^{3}$. Different techniques such as local anesthesia, sedoanalgesia, general anesthesia or regional anesthesia are used in circumcision surgery. Often, a caudal block or a dorsal penile block is applied to provide preemptive analgesia in circumcision patients who undergo a surgical day procedure ${ }^{4}$. These block applications reduce the need for analgesics and anesthetic drugs and prolong the pain-free period $^{5,3}$. Both methods are easy and safe to implement. However, some complications of caudal block have been reported in previous studies ${ }^{6}$. Although a range of local anesthetic drugs have been used in pre-emptive caudal block and dorsal penile block applications, bupivacaine is the most commonly used drug at different concentrations and doses $3,5,7$.

The aim of this study was to present our comparative clinical experience in terms of analgesic efficacy and complications related to caudal block and dorsal penile block using bupivacaine for pre-emptive analgesia in circumcision operations.

\section{METHODS}

After the approval of the Ethics Committee numbered 120 dated $06 / 07 / 2018$, the files of 483 patients who had undergone circumcision after a caudal block or dorsal penile block for pre-emptive analgesia between January 2016 and September 2017 were retrospectively analyzed. The patients were divided into two groups as the patients applied with caudal block (Group 1, $\mathrm{n}=311$ ) and dorsal penile block (Group 2, $\mathrm{n}=108$ ). The anesthetic followup forms from the patient files and the 
demographic data from the clinical nurse observation records, the duration of surgery, the duration of anesthesia, the requirement for intraoperative and postoperative analgesic drugs, the time of first analgesic administration and complications were recorded. From the clinics observation records of the patients, the first analgesic medication time and visual analog scale (VAS) scores at the 30th minute, 1st, 3rd, and 6th hours postoperatively, were recorded (Figure 1). Patients who were administered intravenous opioids in the intraoperative period or in the postoperative recovery room due to insufficient analgesic effect after caudal block and dorsal penile block were considered to be failed blocks. A total of 64 patients were excluded from the study; 9 because of drug allergy, 2 for coagulopathy, 8 for mental retardation and 45 with incomplete data (Figure 2).

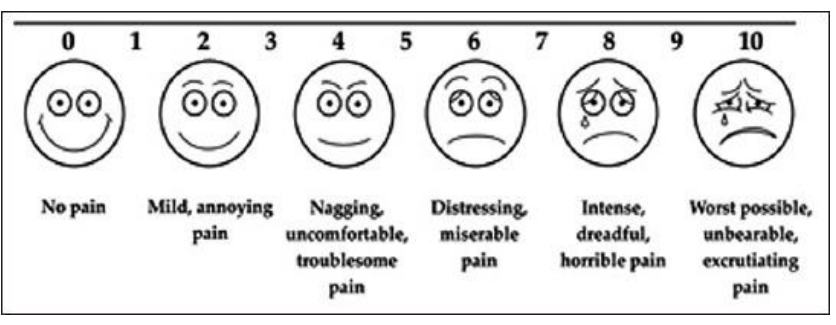

Figure 1. Face Expressions Evaluation Scale

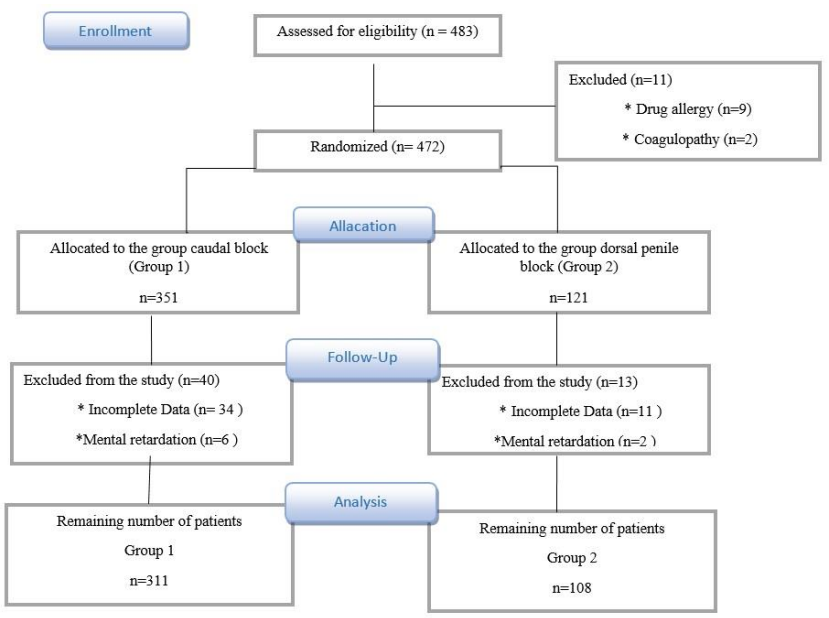

Figure 2. Flow Chart Of The Study
Anesthesia induction was applied with 0.05-0.1 $\mathrm{mg} / \mathrm{kg}$ Midazolam (Dormicum ${ }^{\circledR} 5 \mathrm{mg} / 5 \mathrm{ml}$, Roche, Turkey) and 1-3 mg / kg propofol (1\% Fresenius Propofol@, Turkey) administered intravenously. An additional dose of $1 \mathrm{mg} / \mathrm{kg}$ of propofol was used as needed and mask induction was performed with 3-4 minimum alveolar concentration (MAC) sevoflurane. Laryngeal mask (LMA) was placed in some patients, and mask ventilation was applied to other patients. For the caudal block, a caudal needle (Egemen $\AA 22$ Gauge $32^{\circ}$ Crawford) was used by the same anesthesiologist after the patients were placed in the left lateral decubitus position (Figure 3). For the dorsal penile block, patients were positioned supine, and the same urologist performed the injection from two different points to the penis root after necessary sterilization (Figure 4). The patients in both groups were administered $0.5 \mathrm{ml} / \mathrm{kg}$ $0.25 \%\left(1 \mathrm{mg} / \mathrm{kg}\right.$ ) bupivacaine (Marcaine ${ }^{\circledR}$, Astra- Zeneca, Turkey) as local anesthetic. In both applications, the surgical incision was allowed after adequate anesthesia depth was obtained. In patients with intraoperative increase heart rate, an additional $1 \mathrm{mcg} / \mathrm{kg}$ fentanyl was administered and this was evaluated as insufficient analgesia. These patients and patients in need of analgesic agent in postoperative care unit were accepted as failed blocks.

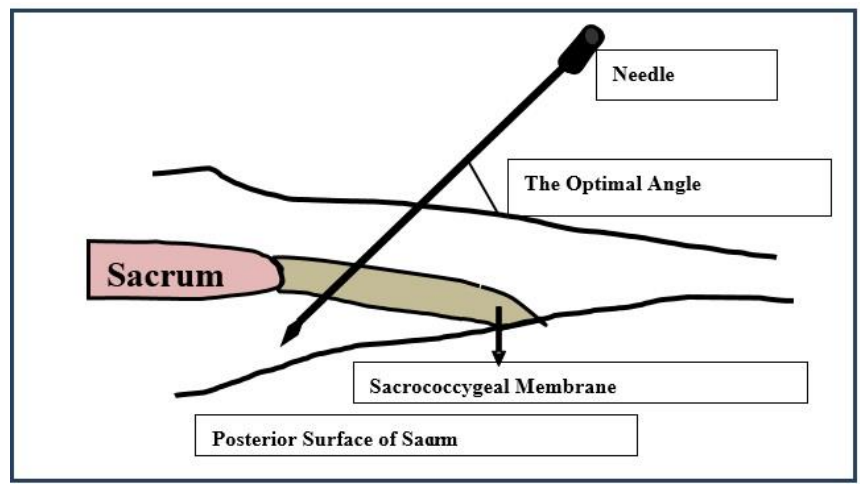

Figure 3. Caudal Block Technique 


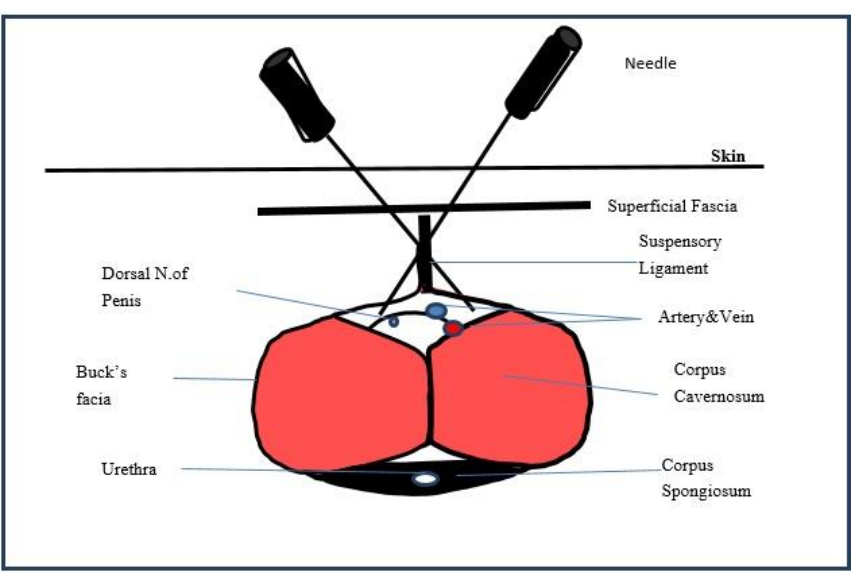

Figure 4. Dorsal Penile Block Technique

\section{Statistical Analysis}

SPSS 16.0 for Windows program was used for statistical analysis. Numerical data were expressed as mean \pm standard deviation (SD) values, and categorical data as frequency and percentage. Conformity of the data to normal distribution was assessed with the Kolmogorov-Smirnov test and results were given as \%n. Comparisons of categorical data were made using the Chi-square test. For data not showing normal distribution, the MannWhitney U-test and the Kruskal Wallis test were applied and the results were stated as median (minimun-maximum) values. A value of $\mathrm{p}<0.05$ was considered statistically significant. This study was carried out in accordance with the Helsinki Declaration 2008 criteria.

\section{RESULTS}

The age, duration of anesthesia and duration of surgery of the children included in the study are shown in Table-1. There was a statistically significant difference in age between the groups. The duration of anesthesia and the duration of surgery were similar (Table 1).

Unsuccessful block was detected in 25 (8\%) of 311 patients in Group 1, and in 9 (8.3\%) of 108 patients in Group 2. No statistically significant difference was found between the groups (Table 2).
The number of patients who needed analgesic drugs in the first postoperative 6-hour period was $20(6.4 \%)$ in Group 1, and 86 (79.6\%) in Group 2. In Group 2, the number of patients who needed analgesic drugs in the first postoperative 6-hour period was higher and statistically significant (Table 2).

Table I: Demographic data of patients, mean anesthesia duration and duration of surgery (Mean \pm SD1)

\begin{tabular}{|llll|}
\hline & $\begin{array}{l}\text { Group 1 } \\
(\mathbf{n}=\mathbf{3 1 1})\end{array}$ & $\begin{array}{l}\text { Group 2 } \\
(\mathbf{n = 1 0 8})\end{array}$ & $\mathbf{p}^{2}$ \\
\hline $\begin{array}{l}\text { Age (years) } \\
\begin{array}{l}\text { Duration of } \\
\text { anesthesia (minute) }\end{array}\end{array}$ & $4.10 \pm 2.12$ & $2.81 \pm 2.87$ & $<\mathbf{0 . 0 0 1 *}$ \\
$\begin{array}{l}\text { Surgical } \\
\text { time(minute) }\end{array}$ & $17.96 \pm 3,37$ & $21.16 \pm 3.45$ & 0.333 \\
\hline
\end{tabular}

1 Average \pm Standard Deviation; 2Mean Whitney U test $p$ value; * Statistically significant

Table II: The number of children who required additional analgesia (failed block), the number of children who required analgesia in the first 6-hour period and the complication rates

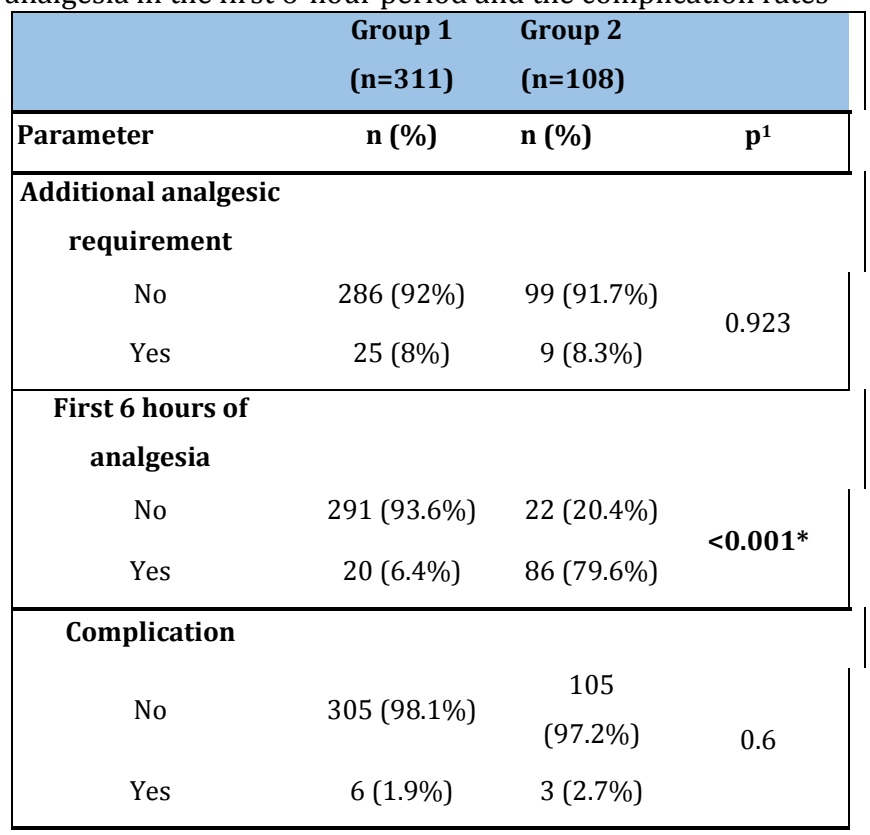

1 Chi-square test $\mathrm{p}$-value * Statistically significant

Postoperative complications were detected in 6 (1.9\%) patients in Group 1, and in $3(2.7 \%)$ in Group 2. All of the complications were nausea 
and vomiting, and none of the patients had complications such as hypotension, bradycardia, difficulty in breathing, urinary retention, prolonged motor weakness (Table 2).

When the groups were compared in terms of VAS scores, there was no significant difference between the groups at 30 mins and 1 hour. At the 3rd and 6th hours, statistically significantly low values were determined in Group 1 (Table 3).

Table III: Mean VAS scores and postoperative analgesia time of the groups

\begin{tabular}{|c|c|c|c|}
\hline & $\begin{array}{l}\text { Group } 1 \\
(n=311)\end{array}$ & $\begin{array}{l}\text { Group } 2 \\
(n=108)\end{array}$ & $\mathbf{p}$ \\
\hline VAS $^{1}$ score (30. min) & 2.21 & 2.26 & 0.715 \\
\hline VAS score (1. hour) & 2.02 & 2.12 & 0.567 \\
\hline VAS score (3. hour) & 2.02 & 3.74 & $<0.001^{*}$ \\
\hline VAS score (6. hour) & 1.37 & 5.42 & $<0.001^{*}$ \\
\hline $\begin{array}{l}\text { Postoperative } \\
\text { analgesia time } \\
\text { (Time to first } \\
\text { analgesia) }\end{array}$ & $435 \pm 69 \mathrm{~min}$ & $228 \pm 124 \mathrm{~min}$ & $<0.001 *$ \\
\hline
\end{tabular}

The mean duration of postoperative analgesia and initial analgesic requirement were $7.25 \pm$ 1.15 hours in Group 1 and $3.80 \pm 2.07$ hours in Group 2. The duration of postoperative analgesia was statistically significantly longer in Group 1 (Table 3).

\section{DISCUSSION}

Circumcision is the process of surgical removal of the prepicium in children, which has been applied for thousands of years in Middle Eastern societies based on religious, cultural and traditional beliefs. As this process causes severe pain in the child, circumcision is carried out in a festive atmosphere that will delight children in many societies to prevent trauma during the procedure. Although this procedure is out patients and minor surgical procedure, the child and parents are seriously worried about the pain. Many methods have been applied to reduce the pain. In contemporary modern medical practice, caudal block and dorsal penile block are two of the preferred methods for this purpose $e^{4,6,8}$.

Bupivacaine is one of the most commonly used local anesthetics for caudal block and dorsal penile block and it is used in different doses and concentrations $\mathrm{s}^{9,10}$. Adjuvant agents such as morphine, fentanyl, ketamine and neostigmine are widely used to improve the duration of effect and the quality of analgesia of the caudal block $^{6,11}$. Locatelli et al. ${ }^{12}$ compared the efficacy and safety of different local anesthetics in a study of 99 children to whom caudal block was applied at a dose of $0.5-1 \mathrm{ml} / \mathrm{kg}$, and reported that the postoperative analgesic block duration of bupivacaine was longer than that of other local anesthetics. In addition, Haliloğlu et al. stated that a $0.2 \mathrm{ml} / \mathrm{kg}$ dose of $0.25 \%$ bupivacaine was effective and safe in caudal block and dorsal penile block ${ }^{13}$. In the current study, successful analgesia was obtained in both caudal and dorsal penile block with bupivacaine at a dose of $0.5 \mathrm{ml} / \mathrm{kg}$ and $1 \mathrm{mg} /$ kg without using any adjuvant agent.

Although the pre-emptive caudal block and dorsal penile block provide effective and adequate analgesia, there is a possibility of failure of the block. Failed blocks may cause severe pain in children. Therefore, insufficient analgesia increases the use of additional opioid drugs in the intraoperative and postoperative period. In previous studies, intraoperative additional opioid has been used to provide adequate analgesia in the failed blocks, and these patients were considered as failed blocks, with no difference between the two groups in terms of block failure ${ }^{3,14,15}$. 
Demiraran et $\mathrm{al}^{8}$. compared caudal block and dorsal penile block with bupivacaine and reported a failure rate of $1.7 \%$ in the caudal group and $2 \%$ in the penile group. In another study by Azerfarin et al. using bupivacaine, additional analgesia was required by 1 (2.3\%) patient in the caudal group, and 3 patients (7.4\%) in the penile group and these patients were evaluated as failed block ${ }^{16}$. In our study, opioid was used as an additional analgesic in $8 \%$ of the patients undergoing caudal block, and in $8.3 \%$ of patients with dorsal penile block in the intraoperative period or in the recovery room and these blocks were considered to be failures. There was no significant difference between the groups in terms of additional opioid use. Block failure can be considered to be caused by practical error together with anatomic and technical difficulties. With the use of ultrasound during applications, the success rate of the block can be increased.

Postoperative analgesia time is also an important factor in the selection of caudal block or dorsal penile block for pre-emptive analgesia. Studies have reported that dorsal penile block application with bupivacaine provides an average of 4-6 hours of analgesia ${ }^{14,17}$. Haliloğlu et al. and Konar et al. found no superiority of caudal block and dorsal penile block using bupivacaine in terms of postoperative analgesia duration ${ }^{13,15}$. However, there are contrasting opinions. Patel et al. identified the period of postoperative analgesia with bupivacaine as $204 \mathrm{~min}$ in the caudal group and $120 \mathrm{~min}$ in the penile group ${ }^{18}$. The duration of postoperative analgesia was determined to be statistically significantly longer in the caudal group. Similar to Patel et al. Polat et al. also used bupivacaine and reported the average period of analgesia to be $480 \mathrm{~min}$ in the caudal group and $360 \mathrm{~min}$ in the penile group, and the difference was statistically significant5. In our study, the postoperative analgesia duration of the patients was $435 \pm 69$ minutes in the caudal block group and $228 \pm$
124 minutes in patients who underwent dorsal penile block group. In terms of postoperative analgesia duration, the results of the our study are similar to those of Polat et al. and contrary to the results of Konar et al. and Haliloglu et al. Furthermore, the number of patients who needed analgesic drugs in the first 6 hours postoperatively was $20(6.4 \%)$ in the caudal block group and 86 (79.6\%) in the dorsal penile block group. Thus, caudal block was determined to provide statistically significantly longer and more effective postoperative analgesia than the dorsal penile block. The results of this study were seen to be consistent with those of many studies in literature regarding the duration of postoperative analgesia.

Postoperative analgesia adequacy in pediatric patients undergoing outpatient surgery is commonly evaluated with FLACC (Face, Legs, Activity, Cry Consolability) or VAS scores. In the comparison of caudal block and dorsal penile block evaluated with the FLACC pain scale, Konar et al. determined no statistically significant difference between the groups ${ }^{15}$. Güçlü et al. used the VAS score, and reported satisfactory VAS values in both groups, with no statistical difference between the groups19. Bengisun et al.. found that VAS scores were significantly lower in patients with caudal block compared to those with dorsal penile block ${ }^{4}$. The VAS pain scale was used in the our study and although the VAS scores were similar in both groups at the 30th $\mathrm{min}$ and 1st hour, lower VAS scores were recorded in the 3rd and 6th hours in patients who underwent caudal block. In the comparison of pain scores, lower VAS scores in the long-term were determined in the caudal block group compared to the dorsal penile block group, in contrast to the findings of Güçlü et al. Therefore, it was concluded that caudal block provides more effective postoperative analgesia and patient satisfaction than the dorsal penile block. 
Nausea and vomiting are the most common complications in caudal block ${ }^{3,4,8}$. However, in most studies, low complication rates have been reported for both caudal block and dorsal penile block, with no superiority of one over the other and it has been stated that both techniques could be used safely ${ }^{3,4,13}$. Some investigators have reported no complications or side effects in any patient who underwent caudal block ${ }^{1,9,15}$. Polat et al. observed nausea and vomiting in 4 (14.8\%) patients in the caudal block group, and in (3.3) patient in the penile block group5. They also emphasized that with the exception of numbness in the lower limb in 2 patients, no motor block developed and there was no statistically significant difference between the groups in terms of complication development. In our study, nausea and vomiting were observed in 6 patients $(2.8 \%)$ of those who were applied caudal block and in 3 patients $(2.1 \%)$ of those who were applied dorsal penile block. No statistically significant difference was determined between the two groups in terms of complication development.

In conclusion, a comparison was made in this study of pre-emptive caudal block and dorsal penile block in outpatient circumcision surgery, and it was determined that the duration of analgesia was longer and fewer patients required additional analgesia in the postoperative period in the group applied caudal block. In addition, the VAS scores were observed to be lower in patients with caudal block in the postoperative period. Therefore, both caudal block and dorsal penile block can be applied safely as analgesia to patients undergoing circumcision. However, caudal block should be preferred to dorsal penile block in clinical use because of the advantage of providing longer postoperative analgesia.

Data Availability: The data used to support the findings of this study are included within the article.
Disclosures: Each author contributed equally to the development of this manuscript.

Financial Disclosure: No funding was used toward the development of this study and there are no financial interests related to this work.

Conflicts of Interest: The authors declare that they have no conflicts of interest.

\section{REFERENCES}

1. Morrison $\mathrm{K}$, Herbst $\mathrm{K}$, Corbett $\mathrm{S}$, et al. Pain Management Practice Patterns for Common Pediatric Urology Procedures. Urology 2014; 83: 206-10.

2. Ödeș R, Erhan ÖL, Demirci M, et al. Effects of ketamine added to ropivacaine in pediatric caudal block. Ağrl 2010; 22: 53-60.

3. Markakis DA. Regional anesthesia in pediatrics. Anesthesiol Clin North Am 2000; 18: 355-81.

4. Canakci E, Yagan $\mathrm{O}$, Tas $\mathrm{N}$, et al. Comparison of preventive analgesia techniques in circumcision cases : Dorsal penile nerve block, caudal block, or subcutaneous morphine? J PakMed Assoc 2017; 67: 159-65.

5. Polat R, Akin M, Keskin G, et al. Comparison of dorsal penile block and caudal block with bupivacaine and oral ibuprofen in children undergoing circumcision. Journal of Anesthesia - JARSS 2015; 23: 238 - 43.

6. Mendil Erdoğan N, Kaymak S, Uğuz M, et al. Kaudal Anestezinin Analjezik Etkisinin Değerlendirilmesi : Retrospektif Çalışma. J Contemp Med 2015; 5: 26-30.

7. Bengisun ZK, Ekmekci $\mathrm{P}$, Haliloğlu AH. Levobupivacaine for postoperative pain management in circumcision: Caudal blocks or dorsal penile nerve block. Ağrı 2012; 24: 180-6.

8. Demiraran Y, Akman Y, İlçe Z, et al. Comparison of Postoperative Analgesic Efficacy of Dorsal Penile Nerve Block Versus Single Dose Caudal Epidural Block for Penile Surgery in Children. Kocatepe Tıp Dergisi 2005; 6: 47-52.

9. Bilgen S, Koner O, Menda F, et al. A comparison of two different doses of bupivacaine in caudal anesthesia for neonatal circumcision. A randomized clinical trial. Middle East J Anesthesiol 2013; 22: 93-8. 
10. Akbas M, Titiz TA, Ertugrul F, et al. Comparison of the effect of ketamine added to bupivacaine and ropivacaine, on stress hormone levels and the duration of caudal analgesia. Acta Anaesthesiol Scand 2005; 49: 1520-6.

11. Chertin B, Zeldin A, Kocherov S, et al. Use of Caudal Analgesia Supplemented with Low Dose of Morphine in Children Who Undergo Renal Surgery Curr Urol 2015; 9: 132-7.

12. Locatelli B, Ingelmo $\mathrm{P}$, Sonzogni V, et al. Randomized, double-blind, phase III, controlled trial comparing levobupivacaine $0.25 \%$, ropivacaine $0.25 \%$ and bupivacaine $0.25 \%$ by the caudal route in children. British Journal of Anaesthesia 2005; 94: 366-71.

13. Haliloglu AH, Gokce MI, Tangal S, et al. Comparison of Postoperative Analgesic Efficacy of Penile Block, Caudal Block and Intravenous Paracetamol for Circumcision : A prospective Randomized Study. Int Braz J Urol 2013; 39: 551-7.

14. Beyaz SG. Comparison of postoperative analgesic efficacy of caudal block versus dorsal penile nerve block with levobupivacaine for circumcision in children. The Korean Journal of Pain. 2011; 24: 31-5.
15. Konar N, Salunke B, Pathak K, et al. Original Research Paper Anaesthesiology A comparison of Dorsal penile nerve block vs. Caudal block for circumcision in children in a rural setup. Global Journal For Research Analysis 2017; 6: 47-9.

16. Azerfarin R, Amiri M, Seyedhejazi M, et al. Comparing caudal and penile nerve blockade using bupivacaine in hypospadias repair surgeries in children. Afr J Paediatr Surg 2011; 8: 294-7.

17. Ashrey E, Bosat B. Single-injection penile block versus caudal block in penile pediatric surgery. AinShams Journal of Anesthesiology 2014; 07: 428-33.

18. Patel S, Shah S, Parmar H. Comparison of postoperative analgesic efficacy of caudal block versus dorsal penile nerve block with bupivacaine for circumcision in children. Int J Med Sci Public Heal 2015; 4: 233-6.

19. Güclü ÇY, Meco BC, Yilmaz AA. Comparison between penile block and caudal block with ropivacaine in children undergoing circumcision. Journal of Anesthesia - JARSS 2014; 22: 153-8. 